\title{
HAK MEWARIS MENURUT KETENTUAN HUKUM WARIS PERDATA
}

Oleh:

\author{
Elviana Sagala, SH, M.Kn
}

Dosen Tetap STIH Labuhan Batu

e-mail : elviana.sagala77@yahoo.com

\begin{abstract}
ABSTRAK
Hukum Waris adalah hukum yang mengatur tentang peralihan harta kekayaan yang ditinggalkan seseorang yang meninggal serta akibatnya bagi ahli waris atau para ahli warisnya. Hukum waris perdata merupakan Hukum waris bagi golongan tionghoa yang ada di Indonesia dan di atur dalam Kitab Undang-undang Hukum Perdata (KUHPerdata). Dalam pembahagian Hukum waris perdata ditentukan dengan dua pembahagian yaitu dengan cara ab intestato dan testamenteir. Namun penulis melihat kebanyakan masyarakat tidak mengerti tentang Hukum waris, sehingga di masyarakat berkembang dengan pembahagian yang adil adalah bagi rata atau porsi yang sama dengan tidak membedakan antara anak laki-laki dan anak perempuan . dalam pembahagian waris perdata juga di atur tentang pergantian tempat, penolakan warisan. Untuk itu perlu sekali untuk menjelaskan kepada masyarakat tentang hukum waris perdata. Hal ini diperlukan untuk menghindarkan masalah dalam pembahagian warisan bagi golongan lain yang ingin mengabaikan aturan Hukum waris yang harusnya dia pakai bukan Hukum waris perdata.
\end{abstract}

Kata Kunci : Hak Waris, Perdata, Porsi Sama

\section{PENDAHULUAN}

Hukum waris menurut A. Pitlo yaitu Hukum waris adalah perkumpulan peraturan yang mengatur mengenai kekayaan kerena wafatnya seseorang, yaitu mengenai pemindahan kekayaan yang ditinggalkan oleh si mati dan akibat dari pemindahan ini dari orang-orang yang memperolehnya, baik dalam hubungan antara mereka maupun dalam hubungan antara mereka dengan pihak ketiga. Sedangkan menurut Subekti, meskipun tidak menyebutkan defenisi Hukum kewarisan beliau menyatakan Hukum waris ssebagai berikut: dalam Hukum waris kitab undang-undang Hukum perdata berlaku suatu asa, bahwa hanyalah hak dan kewajiban dalam lapangan hukum, kekayaan harta benda saja yang dapat diwariskan. Oleh karena itu, hak dan kewajiban dalam lapangan Hukum kekeluargaan pada umumnya hak keperibadian, misalnya hak dan kewajiban sebagai seorang suami atau sebagai seorang ayah tidak dapat diwariskan, begitu pula hak dan kewajiban seorang sebagai anggota perkumpulan.

Dalam hal kali ini Penulis ingin membahas tentang Hukum waris perdata. Hukum kewarisan yang diatur di dalam KUHPerdata diberlakukan bagi orangorang Eropa dan mereka yang 
dipersamakan dengan orang-orang Eropa tersebut, termasuk Tionghoa.

Pewarisan dalam KUHPerdata terdapat dalam Buku ke II mengenai Kebendaan pada Bab kedua belas tentang pewarisan karena kematian. Ketentuan ini dimulai dari pasal 830 KUHPerdata sampai dengan Pasal 1130 KUHPerdata.

Dimana yang menjadi dasar Hukum ahli waris dapat mewarisi sejumlah harta pewaris menurut system Hukum waris BW adalah melalui dua hal:

1. Menurut ketentuan undang-undang (ab intestato atau wettelijk erfrecht)

2. Ditunjuk dalam surat wasiat (testamenteir erfrecht)

Adapun menurut ketentuan Undangundang ( $a b$ intestato atau wettelijk erfrecht), yaitu ahli waris yang mendapatkan bagian warisan karena hubungan kekeluargaan yang berdasarkan pada keturunan (832 BW). Dan apabila pewaris menentukan sendiri tentang harta kekayaannya sehingga dalam hal ini pewaris membuat surat wasiat (testamenteir erfrecht) (899 BW).

Mengingat bahwa ada tiga pembahagian Hukum waris yang berlaku di Indonesia yaitu Hukum waris perdata, Hukum waris Islam dan Hukum waris adat. Ketiga pembahagian Hukum waris ini tentu telah ada aturan Hukum yang berlaku dan tidak salah paham dala arti Hukum waris. Penulis melihat banyak yang tidak mengerti tengang cara

pembahagian hukum waris yang mengatur kehukum mana para ahli waris menyelesaikan pembahagian harta warisan yang ditinggalkan pewaris. Karena itu dalam hal ini Penulis lebih focus pada pembahagian Hukum waris yang berlaku bagi golongan Tionghoa yang ada di Indonesia.

\section{METODE PENELITIAN}

Metode penelitian yang digunakan pada penelitian ini yaitu menggunakan metode Yuridis Normatif yaitu mengacu kepada ketentuan ketentuan peraturan perundang-undangan positif di Indonesia khususnya peraturan perundangan tentang Hukum Waris Perdata yang diatur dalam Kitab Undang-undang Hukum Perdata.

Dalam penelitian ini, akan diteliti data sekunder. Dengan demikian ada dua kegiatan utama yang dilakukan dalam melaksanakan penelitian ini, yaitu studi kepustakaan (Library Research), yang diperoleh melalui kepustakaan, dengan mengkaji, menelaah dan mengolah literatur, peraturan perundang-undangan, artikel-artikel atau tulisan yang berkaitan dengan permasalahan yang akan diteliti.

\section{PEMBAHASAN}

Hukum waris adalah peraturan Hukum yang mengatur perpindahan harta kekayaan dari pewaris kepada para ahli 
waris. Dalam hal pembahagian warisan terlihat sangat sederhana sekali dan hal yang biasa, dalam benak kebanyakan masyarakat bila ada kematian maka yang terpikir yaitu warisan atau harta yang ditingalkan. Namun pembahagian harta warisan tidak semudah yang kita bayangkan, sebab banyak hal yang harus diperhatikan agar tidak terjadi masalah Hukum. Ketidak tauan semua para ahli waris dalam masalah Hukum waris membuat banyak nya terjadi ketidak adilan dalam pembahagian warisan. Ada pula sebahagian masyarakat tidak mengetahui Hukum mana yang mengatur tentang pembahagian warisan mereka. Sehingga sering warisan menjadi seperti ada defenisi yang berkembang di masyarakat yaitu bagi rata saja kan adil. Hal ini penulis melihat kebiasaan yang tertib dalam hal pembahagian warisan yang dilakukan oleh golongan Tionghoa sehingga yang sering di ingat masyarakat pembahagian warisan itu adalah secara Hukum perdata. Untuk itu Penulis ingin menguraikan tentang apakah itu Hukum waris perdata.

pertama kali kita harus mengetahui 3 syarat terjadinya pewarisan yaitu:

1. Adanya yang meninggal dunia (Pewaris).

2. Ada orang yang masih hidup, sebagai ahli waris dari pewaris tersebut (ahli waris)
3. Adanya sejumlah harta kekayaan yang di tinggalkan oleh pewaris (harta warisan)

Pewaris adalah orang yang telah meninggal dunia yang oleh Hukum yang memiliki harta kekayaan maupun hak dan kewajiban yang oleh Hukum dapat diwariskan.

Menurut Eman Suparman seseorang yang meninggal dunia, baik laki-laki maupun perempuan yang meninggalkan sejumlah harta kekayaan baik berupa hak maupun kewajiban yang harus dilaksanakan selama hidupnya, baik dengan surat wasiat maupun tanpa surat wasiat.

Hak dan kewajiban dalam hal ini adalah hak dan kewajiban yang dilakukan oleh pewaris sebelum meninggal dunia terhadap harta kekayaannya. Pengertian ahli waris adalah orang-orang yang didalam KUHPerdata adalah yang berhak menerima harta warisan pewaris dan di perbolehkan oleh Hukum. Ahli waris dapat juga tidak dapat mewarisi harta warisan dari sipewaris bila ahli waris tersebut melakukan hal yang dilarang undang-undang untuk menerima warisan.

Ahli waris yang tidak dapat menjadi ahli waris atau tidak patut jadi ahli waris (pasal 838 BW) yaitu:

1. Orang yang telah dihukum karena membunuh atau mencoba membunuh pewaris. Dalam hal ini sudah ada keputusan hakim, akan tetapi jika 
sebelum keputusan hakim dijatuhkan, sipembunuh telah meninggal dunia, maka ahli warisnya dapat menggantikan kedudukan nya. Pengampunan (grasi) tidak dapat menghapuskan keadaan tidak dapat patut mewaris.

2. orang yang dengan keputusan hakim, pernah dipersalahkan memfitnah pewaris, berupa fitnah dengan ancaman hukuman lima tahun atau lebih berat. Dlam hal ini harus ada keputusan hakim yang menyatakan, bahwa yang bersangkutan bersalah karena memfitnah.

3. Orang yang karena kekerasan atau perbuatan telah mencegah si pewaris untuk membuat atau mencabut surat wasiatnya.

4. Orang yang menggelapkan, merusak atau memalsukan surat wasiat pewaris.

Akan tetapi selain hal tersebut ada juga akibat penolakan warisan, yaitu ahli waris melakukan penetapan pengadilan (Pasal 1057 BW) tidak menginginkan warisan dari si pewaris (pasal $1058 \mathrm{BW}$ ) yaitu si waris yang menolak warisannya, dianggap tidak pernah telah menjadi waris.

Harta warisan adalah seluruh harta benda beserta hak dan kewajiban pewaris dalam lapangan Hukum harta kekayaan yang dapat dinilai dengan uang.

Dalam pembahagian harta warisan menurut Hukum perdata setelah terpenuhinya ketiga syarat tersebut maka dilihat golongan ahli waris yang hidup. Dalam Hukum waris perdata dibagi atas empat golongan yaitu:

1. Ahli waris golongan I yaitu meliputi anak-anak garis lurus ke bawah (pasal $852 \mathrm{BW}$ ), suami atau isteri, anak luar kawin yang di akui sah, anak adopsi yang diangkat dengan penetapan pengadilan dan dipersamakan dengan anak sah.

2. Ahli Waris golongan ke II yaitu ayah dan ibu garis lurus keatas dan saudara saudari (Pasal 854, 857, dan 859 BW).

3. Ahli waris golongan ke III yaitu, kakek dan nenek garis lurus ke atas (Pasal 850, 853 BW).

4. Ahli waris golongan ke IV yaitu saudara saudari dari kedua orang tua si pewaris atau dapat juga golongan ke III dan ke IV bersamaan mewaris (Pasal 858 BW).

Dalam hal pembahagian harta warisan terlebih dahulu diperhatikan golongan yang menerima warisan bila tidak ada wasiat. Setelah hal tersebut ditentukan maka hal-hal yang perlu diperhatikan ada beberapa hal lagi.

Tiga golongan anak menurut KUHPerdata yaitu;

1. Anak sah, yaitu anak yaitu anak yang lahir akibat suatu perkawinan yang sah. Ketentuan ini diatur dalam Pasal 42 Undang-undang Nomor 1 Tahun 1974 
yang berbunyi; anak yang sah ada,ah anak yang dilahirkan dalam atau sebagai akibat perkawinan yang sah. Dan dalam KUHPerdata juga diatur dalam pasal 250 KUHPerdata yaitu tiap-tiap anak yang dilahirkan atau ditumbuhkan sepanjang perkawinan memperoleh si suami sebagai bapaknya. Artinya dalam hal ini harus benar di teliti sesuai dengan bukti-bukti yang menurut undang-undang adalah anak sah.

2. Anak Luar kawin diatur dalam pasal 43 ayat (1) Undang-undang Nomor 1 Tahun 1974. Anak diluar perkawinan adalah anak yang dilahirkan diluar perkawinan dan hanya mempunyai hubungan perdata dengan ibunya serta keluarga ibunya. Dan akibat putusan Mahkamah Konstitusi Nomor 46/PUUVIII/2010 tanggal 17 Pebruari 2012 menyatakan bahwa pasal 43 ayat (1) tersebut harus dibaca anak yang dilahirkan dari luar perkawinan mempunyai hubungan perdata dengan ibunya dan keluarga ibunya serta dengan laki-laki sebagai ayahnya yang dapat dibuktikan berdasarkan ilmu pengetahuan dan tekhnologi dan/atau alat bukti lain menurut Hukum mempunyai hubungan darah termasuk hubungan perdata dengan keluarga ayahnya. Akan tetapi lain halnya anak luar kawin yang di maksud dalam pasal 285 KUHPerdata yaitu pengakuan yang dilakukan sepanjang perkawinan oleh suami atau isteri atas kebahagiaan anak luar kawin yang sebelum kawin olehnya diperbuahkan dengan seorang lain daripada isteri atau suaminya, tak akan membawa kerugian baik isteri atau suami itu, maupun bagi anak - anak yang dilahirkan dari perkawinan mereka. Dalam hal ini anak tersebut masuk pada golongan pertama namun mempunyai batasan dalam pembahagian warisan yang tidak sama porsinya dengan anak sah.

3. Pengangkatan anak (adopsi)

Dalam hal ini staatsbland tahun 1917 Nomor 129 tetang pemberlakukan BW atas golongan Timur Asing Tionghoa dimasukkan dalam pasal-pasal yang mengatur tentang pengangkatan anak, yang dalam hal itu yang boleh didopsi hanya anak laki-laki saja. Tetapi dalam SEMA Nomor 6 tahun 1993 memutuskan bahwa anak perempuan juga dapat diadopsi, dalam hal tata cara mengadopsi anak harus dengan penetapan pengadilan dan izin Menteri Sosial. Dan telah diubah dengan Peraturan Menteri Sosial Republik Indonesia Nomor 110/HUK/2009 Tentang Persyaratan Pengangkatan Anak .

Dalam hal tersebut diatas setelah jelas secara undang-undang yang merupakan ahli waris maka harus diperhatikan lagi adakah ahli waris yang 
meninggal terlebih dahulu dari si Pewaris maka dalam hal pembahagian warisan Perdata dikenal juga dengan pergantian tempat (plaatsvervulling) sebagaimana dimaksud dengan Pasal 841,842, 848, 866, 871 dan ayat 2 Pasal 156 KUHPerdata .

Setelah jelas semua ahli waris maka para ahli waris juga harus semua menerima pembahagian warisan tersebut baru dapat di bagi, akan tetapi ahli waris juga dapat menolak untuk menerima harta warisan tersebut. Dalam hal para ahli waris atau sebahagian ahli waris merasa ragu tentang harta warisan tersebut maka diberi waktu 4 bulan sejak permohonan pernyataan sebagaimna dimaksud dalam Pasal 1023 KUHPerdata, hal tersebut dilakukan untuk mengetahui tentang aktiva dan fasiva, sehingga ahli waris dapat mengetahui apakah ada lagi warisan yang bersisa. Dalam BW pasal 1029 BW apabila 4 bulan telah selesai dilaksanakan maka wajib para ahli waris menntukan sikap yaitu:

1. Menerima secara murni (pasal 1048 KUHPerdata)

2. Menerima dengan hak mengadakan pendaftaran harta peninggalan (1032 KUHPerdata) atau

\section{Menolak warisan (1057 KUHPerdata)}

Maka dengan memperhatikan semua hal untuk dapat menentukan ahli waris yang berhak atas harta warissan si pewaris harus lah benar benar teliti, tidak cukup hanya mengetahui ahli waris yang sah tetapi banyak hal yang harus diperhatikan untuk tidak terjadi kesalahan dalam menentukan ahli waris.

Sehingga bila telah dapat ditetapkan ahli waris makapenulis akan menguraikan secara garis besar tentang pembahagian ahli waris dan cara membagi warisan berdasarkan golongan.

A. Ahli waris Golongan I (Pertama)

Pasal 852 KUHPerdata dimana dalam pasal ini di jelaskan bahwa baik anak laki-laki dan anak perempuan itu memiliki hak yang sama atau di kenal dengan bagi rata. Yang berbeda adalah bahagian anak luar kawin atau anak adopsi yang dalam penetapan pengadilan tidak disebutkan dengan tegas kedudukannya sama dengan anak sah.

B. Ahli waris golongan ke II (kedua),

Ahli waris golongan kedua ini yaitu keluarga dalam garis lurus ke atas Meliputi orang tua, saudara-saudara laki-laki dan perempuan dan keturunannya. Pembahagian harta peninggalan ini diatur dalam pasal 854, 855, 857, 859 KUHPerdata.

C. Ahli Waris Golongan ke III (ketiga)

Ahli waris golongan ketiga ini yaitu keluarga sedarah dalam garis lurus keatas jika sipewaris tidak meninggalkan keturunan maupun suami atau isteri, orang tua, saudara saudari maupun keturunannya. Hal ini di atur dalam pasal $850 \mathrm{BW}$ dan pasal 853 ayat (1) dan ayat (3) BW, bahwa harta peninggalan harus di bagi dua bahagian sama besarnya, satu bahagian 
untuk semua keluarga sedarah dalam garis lurus keatas, dan satu bahagian lagi untuk semua keluarga seddaarah dalam garis si ibu.

D. Ahli Waris Golongan IV (Keempat). Dalam hal ini pasal 858 KUHPerdata, Menentukan bahwa dalam hal tidak adanya saudara saudara laki laki dan perempuan dann tidak adanya pula keluarga dalam garis lurus keatas, setengah bagian dari warisan menjadi bagian sekallian keluarga dalam garis keatas yang masih hidup, sedangkan ssetengah bagian lainnya, kecuali dalam hal tersebut masih hidup, sedangkan setengah bagian lainnya kecuali dalam hal tersebut dalam pasal 859 menjadi bagian para sanak saudara dalam garis lain. Ahli waris dalam golongan keempat ini yaitu keluarga lainnya dalam garis menyamping yang dibatasi sampai dengan derajat keenam, baik dari pihak ayah maupun dari pihak Ibu.

\section{WASIAT (Testament) dan Hibah wasiat} (Legaat).

Wasiat adalah pembahagian warisan yaitu Wasiat (testament) merupakan pernyataan seseorang mengenai apa yang dikehendaki setelah meninggal dunia. Pada asasnya suatu pernyataan kemauan adalah dating dari satu pihak saja (eenzigdig) dan setiap waktu dapat ditarik kembali oleh yang membuatnya. Wasiat diatur Pasal 875 KUHPerdata adalah suatu akta yang berisi pernyataan seseorang tentang apa yang akan terjadi setelah ia meninggal dunia dan olehnya dapat ditarik kembali.

Seperti di sebutkan di atas tentang pembahagian warisan ab intestao dapat dilakukan bila telah di cek ke Menteri Hukkum Dan Hak Asasi Manusia tidak ada wasiat barulah pembahagian secara Undang-undang (ab intestate) dapat dilakukan. Dan dalam hal wasiat juga harus diperhatikan isi wasiat dan kepatutan seseorang secara Hukum mmebuat wasiat sebagaimana di atur dalam pasal 897 BW. Aturan Hukum yang harus doperhatikan lagi adalah pasal 888, 890, 930 dan 893 BW.

Sedangkan bentuk wasiat di atur dalam pasal 954, 957, 932, 933, 934, 935, 938, 939, 940, 941,942, 945, 946, dst....1022 BW.

Dari hal-hal yang diuraikan Penulis semoga dapat bermanfaat untuk memahami tentang warisan yang diatur dalam KUHPerdata dan kepada siapakah hal ini berlaku.

Sedangkan untuk yang beragama Islam maka harus sesuai dengan Al-qur an dan Al-Hadist. Dan untuk selain itu maka berlaku Hukum adat.

\section{KESIMPULAN DAN SARAN}

\subsection{Kesimpulan}

Berdasarkan uraian-uraian diatas dapat disimpulkan bahwa setiap orang harus mengerti tentang atauran pembahagian harta waarisan, sebab 
harta warisan adalah kepemilikan bersama yang sangat rentan dengan perkara. Tentu setiap ahli waris harus benar-benar dapat melaksanakan pembahagian dengan baik sebagai bukti bahwa kita berbakti atau menghormati pewaris yang merupakan orang yang sangat kita cintai. Dan kalaupun setiap ahli waris menginginkan pembahagian di luar dari ketentuan yang telah ditetapkan asal semua sepakat hal ini juga di perbolehkan. Dalam hal Hukum Islam sudah sepetutnya harus patuh pada perintah Al-qur an dan $\mathrm{Al}$ hadist sebagimana ketertan posri dalam QS. Annisa ayat 11, 12 dan 176 dan ayat lainnya dan hadist yang mengatur hal tersebut. Dan untuk yang bukan beragama Islam dan bukan golongan Tionghoa melaksanakan pembahagian warisan dengan adat yang mengatur dengan memperhatikan

peraturan perundang-undangan yang berlaku di Indonesia. Maka dengan demikian Hukum itu akan tetap berjalan pada mestinya dan di mengerti setiap orang hingga tidak terjadi kebingungan lagi tentang mana yang mengatur. Dengan kepatuhan membuat masalah Hukum tidak akan timbul. Sehingga semua pihak memiliki haknya.
Bahwa pengaturan tentang pembahagian harta warisan itu sudah seharusnya sesuai dengan apa yang telah ditetapkan, agar hal ini dapat terus berlanjut dan dimengerti oleh generasi selanjutnya. Adanya kelonggaran yang diberi bahwa para ahli waris dapat membagi warisan sesuai dengan kesepakatan para ahli waris ini membuat timbulnya keberaneka ragaman pemikiran para ahli waris dengan menjadikan para ahli waris memiliki hak yang berbeda untuk mentukan cara pembahagian harta warisan. Seperti halnya yang beragama Islam ada juga melakukan pembahagian warisan dengan bagi rata dengan mengindahkan ketentuan yang telah di tetapkan dalam Al-qur'an dan AlHadist, sehinga Penulis beranggapan bahwa ini juga dapat memicu perbedaan pendapat merasa ada lagi cara yang lebih adil dari ketetapan yang di berikan Allah. Dan dalam hal pembahagian yang ada dalam KUHPerdata sudah jelas itu adalah untuk golongan Tionghoa dan yang menundukkan diri pada aturan Hukum KHUPerdata. Dan Untuk yang tidak golongan Tionghoa dan bukan beragama Islam maka melaksanakan pembahagian warisan dengan Hukum adat dengan tidak mengindahkan adanya aturan lain 
yang telah menjadi tambahan Hukum

untuk menyelesaikan pembahagian

alhi waris seperti Yurisprudensi atau

putusan Mahkamah Agung Republik

Indonesia dan atuaran lainnya.

Semoga bila setiap orang

menerapkan sesuai dengan ketentuan

maka keberagamana cara untuk

sepakat dan mufakat tak perlu lagi

agar sengketa dapat di hindarkan

dalam penetapan undang-undang atau aturan mana yang mau dipakai lagi.

\section{DAFTAR PUSTAKA}

Badriyah, Harun, 2009. Panduan Praktis Pembagian waris, Yogyakarta: Penerbit Pustaka Yustisia

Kitab Undang-undang Hukum Perdata

Lusiana, Elvi, 2011. Cara Mudah \& Benar Membagi Harta Warga, Jakarta: PT. AgroMedia Pustaka

Perangin, Effendi, 2016. Hukum Waris, Jakarta: PT Rajagrafindo Persada

Suparman, Maman, 2015. Hukum Waris Perdata, Jakarta Timur: Sinar Grafika 